\title{
RESEÑA
}

\section{Una historia de Asia Oriental. De los orígenes de la civilización al siglo XXI}

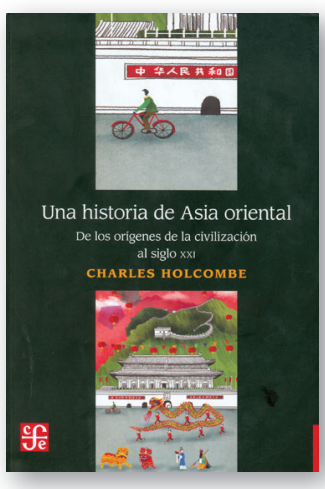

Una historia de Asia Oriental. De los orígenes de la civilización al siglo XXI, Charles Holcombe, traducción de Arturo López Gómez, Fondo de Cultura Económica, México, 2016.

En su libro Una historia de Asia Oriental. De los orígenes de la civilización al siglo XXI, su más reciente obra, el profesor Charles Holcombe, quien ha dedicado su vida al estudio de la historia de China, comenta que, tras la caída del Imperio Romano de Occidente, "el país central" fue probablemente el más rico del mundo durante un milenio; que Japón logró pasar a ser la primera sociedad fuera del mundo occidental en modernizarse exitosamente, y que Corea del Sur, siendo un país moderno, occidentalizado y fuerte aliado de los Estados Unidos es también el país más "confucionista" de Asia del Este. Estos son solo algunos de los interesantes datos que este autor nos ofrece para aproximarse a los países de Asia Oriental que, a decir de él mismo, son junto con Norteamérica y Europa, uno de los tres más grandes centros de riqueza y poder globales desde los inicios del siglo XXI.

1. Universidad de Guadalajara, profesor investigador del Departamento de Estudios del Pacífico del Centro Universitario de Ciencias Sociales y Humanidades. Av. Parres Arias 150, Los Belenes, Zapopan, Jalisco, México. Correo electrónico: rapecor2007@yahoo.com.mx. 
Diversas características hacen que este libro constituya no solo una guía didáctica a través de la historia de la civilización asiática oriental, sino también un viaje fascinante por los países que forman parte de ella: el doble enfoque tanto regional (Asia del Este) como nacional (China, Japón, Corea, Taiwán, Singapur); es decir, de Estados-nación independientes; la visión del autor no solo desde la dimensión macro de la región, sino también el acercamiento hacia la dimensión micro; la historia de vida de los asiáticos orientales, reconstruida a través de la cultura popular; la idea de Asia Oriental no solamente como una civilización cerrada y aislacionista, sino también una civilización abierta, híbrida, multicultural e internacional. Resalta también la perspectiva multidisciplinaria de la obra: histórica, cultural, política, lingüística, religiosa, económica, social y, finalmente, la aproximación del autor hacia el concepto de modernización de esta región del mundo, lo cual no necesariamente está vinculada a la occidentalización y la globalización sino a un proceso de modernización que permite afianzar más las tradiciones, los valores y las ideologías de Asia Oriental, así como la coexistencia entre el Occidente y el Oriente.

Utilizando un orden cronológico, pero no siempre lineal, Charles Holcombe construye una historia de Asia Oriental mediante tres países principales, China, Japón y Corea, entrelazando las historias de esos actores protagonistas de esta región tan próspera y exitosa económicamente a escala mundial. Una de las premisas fundamentales presentes a lo largo de la obra es la existencia de Asia Oriental como una región relativamente homogénea, pero con las identidades nacionales de cada país y sus propias características peculiares, sin dejar a su vez de formar parte de una misma entidad coherente cultural e históricamente en la que cada uno de estos países giran en torno a un eje común: China. De este eje surgen elementos como la escritura, capaz de conformar tanto ideas como valores; el confucionismo, que oscila entre la religión y la filosofía, así como el budismo asiático oriental. Elementos culturales como estos surgen en China y su influencia permea tanto a Japón como a Corea. Posteriormente, cada uno de estos países evoluciona y se distancia poco a poco de la influencia china, hasta alcanzar su propia madurez y conformar sus propias identidades. A pesar de las diferencias, las historias de los países van entremezclándose y formando un entramado común de la misma región geográfica. Este enfoque regional del tipo de los llamados estudios de área considera a Asia Oriental como una unidad de conjunto donde la visión histórica conforma la civilización asiática oriental en torno a la figura de la Gran China; es decir, la actual República Popular China, Hong Kong, Taiwán, Singapur, Corea, Vietnam, con todo su bagaje histórico y milenario, desde los orígenes de la civilización china como la "Cuna de Oriente", 
con sus repercusiones en la región y las diferencias nacionales que mantiene con los otros países que se encuentran bajo su zona de influencia.

Además de estos países protagónicos, el autor menciona otros secundarios, pero no por eso menos importantes, si bien aparecen en la obra de manera más esporádica: Singapur, Taiwán y Vietnam, entre otros. Estos también se relacionan ampliamente con China. Sin embargo, si bien la importancia de China se deja sentir en la obra como el país culturalmente más influyente de la región de Asia Oriental, el autor enfatiza en las grandes diferencias que existen, por ejemplo, entre los sistemas de escritura chino y japonés, entre el tipo de diplomacia que ejercen los Estados Unidos con China y con Japón, o en las diferencias que existen entre dos diferentes Estados chinos: el continental y la isla de Taiwán.

A lo largo de la mayor parte de las páginas que conforman esta obra, Charles Holcombe narra y describe con muchos detalles la manera en que han evolucionado las civilizaciones china, japonesa y coreana a lo largo del tiempo, hasta llegar a ser lo que son actualmente: una historia de éxito económico en el mundo. Esto lo logra utilizando dos dimensiones, la macro y la micro.

Desde la perspectiva macro, el autor narra una historia compleja: Las diferentes dinastías que han gobernado estos países, a través de distintas luchas por el poder, periodos de restauración que han sucedido a gobiernos autoritarios, y distintos tipos de gobiernos que incluyen desde imperios hasta democracias liberales, pasando por regímenes comunistas como el de la República Popular China; las guerras en que estos países han participado, las modificaciones que han tenido sus respectivos territorios que no siempre fueron como son en la actualidad. El autor se detiene, por ejemplo, en la historia del imperio mongol, que llegó a ocupar una vasta extensión territorial que abarcaba Persia, el Tíbet, Indochina, e incluso llegó a Europa del este, en lo que se conoce como el más grande Imperio de toda la historia, y describe los cambios de las capitales políticas de estos países, además de las problemáticas que han tenido que enfrentar sus sociedades a lo largo de una extensa historia que va desde la época premoderna hasta los años de la globalización.

$\mathrm{Al}$ analizar estos temas, el autor nos sumerge en una historia llena de hechos tan contradictorios como sorprendentes: personajes como Sun Yat Sen, que fue un gran nacionalista chino a pesar de haber recibido muchas influencias del extranjero y haber vivido él mismo fuera de su país; un Mao Zedong, que sacó a China de la pobreza, pero con altos costos humanos, y un Den Xiaoping que, gracias a introducir profundas reformas económicas en China, contribuyó a la consolidación de la ideología comunista y del Partido Comunista de China. Sobre Japón, el autor señala que la Constitución Política fue redactada por los Estados Unidos, y sigue vigente 
hasta la actualidad a pesar de los amargos recuerdos que ese país todavía tiene del lanzamiento de las bombas atómicas. De Corea del Norte, Charles Holcombe hace referencia al culto a la personalidad del Gran Líder norcoreano, Kim Il Sung, a través de los más de 35,000 monumentos suyos existentes en ese país.

Por su parte, desde la dimensión micro, el autor retoma varios elementos de la historia cotidiana y de la cultura popular: La invención de la imprenta de madera, que dio lugar a la explosión bibliográfica y a la difusión del confucianismo; la cultura del entretenimiento en Japón: desde el té, las geishas y el teatro kabuki hasta la influencia pop estadounidense en Corea; la repercusión del budismo zen en la cultura japonesa en los jardines de rocas, la poesía o la arquitectura; la popularidad de los automóviles estadounidenses en China; el jazz japonés; la historia del sushi, del tempura, y el karaoke coreano. Quizás el ejemplo más representativo sea Japón, el Estado más estadounidense de Asia Oriental, que tiene incluso una Disneylandia, pero, a pesar de eso, sigue siendo muy japonés.

Un aspecto importante de la obra es que desmitifica que los países asiáticos, y en particular China, hayan sido completamente cerrados, aislacionistas y tradicionales. Plantea más bien que estuvieron expuestos desde la antigüedad al contacto con otras culturas y naciones, al comercio internacional (como ocurrió con la llamada Ruta de la Seda), al mestizaje y las hibridaciones étnicas, lingüísticas, religiosas y culturales; que fueron influidos por la modernidad temprana hasta ser lo que son actualmente: una mezcla de lo nuevo y lo viejo, lo oriental y lo occidental, sin perder su esencia propia ni su identidad. Ejemplo de esto son los hallazgos arqueológicos de porcelana china de que habla el autor, encontrados en Indonesia, Malasia, Filipinas, la India, el este de África, Egipto y el Golfo Pérsico. Habla también de la invención del ábaco y su importancia para el comercio internacional, la llegada de los jesuitas a China, la apertura de los puertos chinos al comercio y las migraciones europeas, así como las colonizaciones que ha habido en enclaves chinos como Hong Kong, Macao, Shanghái o Qindao, donde llegó a haber universidades para extranjeros y periódicos en lenguas de otros países. El mismo autor señala que la civilización china fue siempre una visión multiétnica, nos habla de elementos como el origen manchú del vestido largo conocido con el nombre chino de qipao, y de la religión tibetana como común denominador entre dos pueblos: los mongoles del oeste conocidos como zúngaros, y la dinastía Qing manchú del noreste; de que la dinastía Qing era considerada como "cosmopolita", característica que no es reciente en la civilización china, sino de muchos años atrás. Actualmente, es la globalización como conjunto de influencias modernizadoras lo que ha cuestionado, adaptado o reemplazado las ideas tradicionales de Asia Oriental, pero, a pesar de todo, estas sobreviven todavía y se mantienen vivas. Así, tenemos 
hoy en día remanentes de las monarquías nacionalistas locales en el Emperador japonés, y milenios de unidad política y centralismo en el gobierno de partido único de la República Popular de China.

Las historias se entrelazan. Charles Holcombe nos habla de que, en tiempos de la dinastía Song, China comercializaba con países tan alejados como la España morisca; de los viajes de Marco Polo a China; de las audiencias de los cristianos nestorianos a los reyes de Inglaterra y Francia; de Beijing como capital del imperio mongol. El confucianismo permea Corea y Japón, rutas comerciales globales, como las de los portugueses, incluyen a China en su trayectoria, mientras que en el siglo XVII Li Yu surge como un intelectual chino con ideas modernas. La diversidad cultural de China recibe influencias extranjeras de distancias muy alejadas, mientras la civilización china también alcanza localidades geográficas muy distantes, y se ve influida por los chinos que viajan al extranjero y regresan a su país.

La perspectiva multidisciplinaria resalta a lo largo de las páginas de esta obra tan bien documentada y escrita, en que el autor no solo narra hechos, sino también los analiza, y pasa fácilmente de los sucesos históricos a las etimologías, las aportaciones culturales, filosóficas, religiosas o artísticas de las diferentes civilizaciones, a través de saltos no solo disciplinarios, sino también temporales, que nos permiten entender el origen histórico de algunos elementos de Asia Oriental, razón por la cual ciertas circunstancias de la actualidad de esta región están conectadas con algunos hechos del pasado, o bien compara un mismo elemento cultural en las diferentes civilizaciones china, japonesa o coreana, entre sí o con otras culturas, como el Tíbet, Manchuria o Mongolia. Por ello el análisis que plantea el autor resulta complejo; sin embargo, la manera en que lo aborda y el lenguaje en que está escrito este interesante estudio, resultan claros.

El autor retrata a los países de Asia del este como tradicionales y milenarios, pero a la vez abiertos al mundo e insertos en la cultura global moderna. Este tema, unido con el de la occidentalización es también importante en la obra, entendida esta de una manera diferente a la visión occidental, que divide la historia en Antigüedad, Edad Media y Edad Moderna. La visión de Asia Occidental es diferente por carecer de Edad Media (salvo en Japón que sí tuvo un feudalismo). En China, nos señala el autor, solamente hubo un tiempo premoderno y otro moderno, con una transición en el siglo XIX. La modernidad en China significó abrirse al libre mercado e introducir ferrocarriles veloces, en Japón adoptar una democracia liberal representativa, y en Corea lograr la industrialización al estilo estadounidense. Sin embargo, esta modernización, si bien alcanza niveles envidiables hasta para las sociedades occidentales, mantiene todavía las profundas ideas tradicionales de estos países. En este sentido, 
el autor plantea la paradoja de que el comunismo chino fue una forma de modernización y occidentalización de ese país, debido a que muchos de sus líderes comunistas se formaron en Francia.

Es esta la historia de cómo la región conocida como Asia Oriental se convirtió en exitosa en la actualidad, pero no exenta de la crueldad de las guerras, las pérdidas territoriales y humanas, las crisis económicas y las desigualdades sociales. A pesar de sus complejidades históricas, para el autor Asia Oriental permanece como una región con un gran potencial económico y un futuro sobresaliente que, a pesar de la globalización, ha sabido mantener sus valores locales. ㄲiv 